\title{
Front Matter: Volume 8600
}

, "Front Matter: Volume 8600," Proc. SPIE 8600, Laser Resonators, Microresonators, and Beam Control XV, 860001 (28 March 2013); doi: $10.1117 / 12.2024928$

SPIE. Event: SPIE LASE, 2013, San Francisco, California, United States 


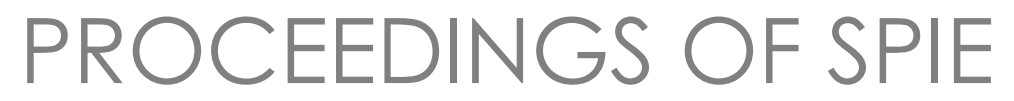

\title{
Laser Resonators, Microresonators, and Beam Control XV
}

\author{
Alexis V. Kudryashov \\ Alan H. Paxton \\ Vladimir S. Ilchenko \\ Lutz Aschke \\ Kunihiko Washio \\ Editors
}

3-7 February 2013

San Francisco, California, United States

Sponsored and Published by

SPIE 
The papers included in this volume were part of the technical conference cited on the cover and title page. Papers were selected and subject to review by the editors and conference program committee. Some conference presentations may not be available for publication. The papers published in these proceedings reflect the work and thoughts of the authors and are published herein as submitted. The publisher is not responsible for the validity of the information or for any outcomes resulting from reliance thereon.

Please use the following format to cite material from this book:

Author(s), "Title of Paper," in Laser Resonators, Microresonators, and Beam Control XV, edited by Alexis V. Kudryashov, Alan H. Paxton, Vladimir S. Ilchenko, Lutz Aschke, Kunihiko Washio, Proceedings of SPIE Vol. 8600 (SPIE, Bellingham, WA, 2013) Article CID Number.

ISSN: 0277-786X

ISBN: 9780819493699

Published by

SPIE

P.O. Box 10, Bellingham, Washington 98227-0010 USA

Telephone +1 3606763290 (Pacific Time) · Fax +1 3606471445

SPIE.org

Copyright (C) 2013, Society of Photo-Optical Instrumentation Engineers.

Copying of material in this book for internal or personal use, or for the internal or personal use of specific clients, beyond the fair use provisions granted by the U.S. Copyright Law is authorized by SPIE subject to payment of copying fees. The Transactional Reporting Service base fee for this volume is $\$ 18.00$ per article (or portion thereof), which should be paid directly to the Copyright Clearance Center (CCC), 222 Rosewood Drive, Danvers, MA 01923. Payment may also be made electronically through CCC Online at copyright.com. Other copying for republication, resale, advertising or promotion, or any form of systematic or multiple reproduction of any material in this book is prohibited except with permission in writing from the publisher. The CCC fee code is 0277-786X/13/\$18.00.

Printed in the United States of America.

Publication of record for individual papers is online in the SPIE Digital Library.

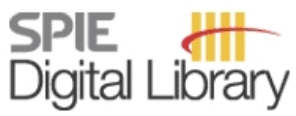

SPIEDigitalLibrary.org

Paper Numbering: Proceedings of SPIE follow an e-First publication model, with papers published first online and then in print and on CD-ROM. Papers are published as they are submitted and meet publication criteria. A unique, consistent, permanent citation identifier (CID) number is assigned to each article at the time of the first publication. Utilization of CIDs allows articles to be fully citable as soon as they are published online, and connects the same identifier to all online, print, and electronic versions of the publication. SPIE uses a six-digit CID article numbering system in which:

- The first four digits correspond to the SPIE volume number.

- The last two digits indicate publication order within the volume using a Base 36 numbering

system employing both numerals and letters. These two-number sets start with 00, 01, 02, 03, 04, $05,06,07,08,09,0 A, 0 B \ldots$. 0Z, followed by 10-1Z, 20-2Z, etc.

The CID Number appears on each page of the manuscript. The complete citation is used on the first page, and an abbreviated version on subsequent pages. Numbers in the index correspond to the last two digits of the six-digit CID Number. 


\section{Contents}

ix Conference Committee

\section{$\mathrm{CO}_{2}$ LASERS AND THEIR BEAMS}

860002 Bistable behavior of a continuous optical discharge as a laser beam propagation effect (Invited Paper) [8600-1]

V. P. Zimakov, V. A. Kuznetsov, A. N. Shemyakin, N. G. Solovyov, A. O. Shilov, M. Y. Yakimov, A. Ishlinsky Institute for Problems in Mechanics (Russian Federation)

860003 Extremely high power $\mathrm{CO}_{2}$ laser beam correction (Invited Paper) [8600-2]

A. Kudryashov, A. Alexandrov, A. Rukosuev, V. Samarkin, Moscow State Open Univ. (Russian Federation)

860004 Optimization of the intra-cavity optical flux in the unstable direction in RF excited annular $\mathrm{CO}_{2}$ laser in terms of power stability [8600-3]

V. Granson, F. J. Villarreal, J. Deile, J. F. Monjardin, S. Sumrain, TRUMPF Inc. (United States)

\section{BEAM QUALITY MEASUREMENTS AND IMPROVEMENT}

860005 Pulse compression and beam quality improvement of a single-frequency Nd:YAG MOPA system [8600-5]

O. Lux, H. Stankov, H. Fritsche, H. J. Eichler, Technische Univ. Berlin (Germany)

860006 Wavefront measurement and data analysis of XUV HHG beam [8600-6]

P. Homer, B. Rus, J. Hrebicek, J. Nejdl, Institute of Physics of the ASCR, v.v.i. (Czech

Republic)

\section{MICRORESONATORS IN FREQUENCY COMBS}

860009 Terabit/s data transmission using optical frequency combs (Invited Paper) [8600-9]

C. Koos, J. Leuthold, W. Freude, Karlsruher Institut für Technologie (Germany);

T. J. Kippenberg, Ecole Polytechnique Fédérale de Lausanne (Switzerland); J. Pfeifle,

C. Weimann, Karlsruher Institut für Technologie (Germany); K. Hartinger, Ecole

Polytechnique Fédérale de Lausanne (Switzerland), and Menlo Systems GmgH (Germany);

$\checkmark$. Brasch, Ecole Polytechnique Fédérale de Lausanne (Switzerland); T. Herr, Ecole

Polytechnique Fédérale de Lausanne (Switzerland); R. Holzwarth, Max Planck Institut für Quantenoptik (Germany), and Menlo Systems GmgH (Germany); D. Hillerkuss,

R. Schmogrow, Karlsruher Institut für Technologie (Germany)

8600 OC On phase locking phenomena in Kerr combs [8600-12]

A. Coillet, I. Balakireva, R. Henriet, L. Larger, Y. Chembo, FEMTO-ST (France) 
MICRORESONATORS IN LASERS, RF PHOTONICS, THZ, AND MID-IR I

8600 OE A solid state ultraviolet lasers based on cerium-doped LiCaAlF 6 crystal resonator (Invited Paper) [8600-14]

N. Yu, T. Le, Jet Propulsion Lab. (United States); S. J. Schowalter, W. Rellergert, J. Jeet, Univ.

of California, Los Angeles (United States); G. Lin, Jet Propulsion Lab. (United States);

E. Hudson, Univ. of California, Los Angeles (United States)

8600 OG High gain selective amplification in whispering gallery mode resonators: analysis by cavity ring down method (Invited Paper) [8600-16]

P. Féron, A. Rasoloniaina, V. Huet, E. Le Cren, CNRS, Ecole Nationale Supérieure des

Sciences Appliquées et de Technologie (France); S. Trebaol, Ecole Polytechnique Fédérale de Lausanne (Switzerland); G. Nunzi Conti, Istituto di Fisica Applicata Nello Carrara (Italy);

H. Serier-Brault, M. Mortier, CNRS, Ctr. National de la Recherche Scientifique (France);

Y. Dumeige, CNRS, Ecole Nationale Supérieure des Sciences Appliquées et de Technologie (France)

MICRORESONATORS IN LASERS, RF PHOTONICS, THZ, AND MID-IR II

8600 OK Chalcogenide glass planar photonics: from mid-IR sensing to 3-D flexible substrate integration (Invited Paper) [8600-20]

H. Lin, L. Li, Y. Zou, O. Ogbuu, The Univ. of Delaware (United States); S. Danto,

J. D. Musgraves, K. Richardson, CREOL, The College of Optics and Photonics, The Univ. of

Central Florida (United States); J. Hu, The Univ. of Delaware (United States)

MICRORESONATORS: CAVITY QED, OPTOMECHANICS, AND FREQUENCY CONVERSION

$8600 \mathrm{OL}$ Bose-Einstein condensation of photons in a microscopic optical resonator: towards photonic lattices and coupled cavities (Invited Paper) [8600-21]

J. Klaers, J. Schmitt, T. Damm, D. Dung, F. Vewinger, M. Weitz, Rheinische Friedrich-

Wilhelms-Univ. Bonn (Germany)

$86000 \mathrm{M}$ Bright squeezed light via second harmonic generation in a whispering-gallery mode resonator [8600-22]

M. T. Simons, I. Novikova, The College of William \& Mary (United States)

860000 RF-induced change of optical refractive index in strontium barium niobate [8600-51]

A. A. Savchenkov, A. B. Matsko, V. S. Ilchenko, I. Solomatine, D. Seidel, L. Maleki, OEwaves, Inc. (United States)

8600 OP High-Q BBO whispering gallery mode resonators [8600-25]

G. Lin, Jet Propulsion Lab. (United States); J. U. Fürst, Jet Propulsion Lab. (United States) and Univ. of Erlangen-Nuremberg (Germany); D. V. Strekalov, I. S. Grudinin, N. Yu, Jet Propulsion Lab. (United States) 
$8600 \mathrm{OR}$ Compact laser beam analyzer with polarization independent optics and wide dynamic range of neutral density adjustment [8600-27]

M. Scaggs, G. Haas, Haas Laser Technologies, Inc. (United States)

8600 OS Recent advances in coupled laser cavity design (Invited Paper) [8600-30]

J. R. Leger, H.-S. Chiang, The Univ. of Minnesota, Twin Cities (United States); J. Nilsson, The Univ. of Southampton (United Kingdom); J. Ji, The Univ. of Southampton (United Kingdom), and Nanyang Technological Univ. (Singapore); J. Sahu, The Univ. of Southampton (United Kingdom)

\section{LASER BEAM FORMATION}

8600 OU Unraveling light with digital holograms (Invited Paper) [8600-32]

A. Forbes, CSIR National Laser Ctr. (South Africa), and Stellenbosch Univ. (South Africa), and Univ. of KwaZulu-Natal (South Africa); C. Schulze, Friedrich-Schiller-Univ. Jena (Germany); S. Ngcobo, CSIR National Laser Ctr. (South Africa), and Univ. of KwaZulu-Natal (South Africa); D. Flamm, Friedrich-Schiller-Univ. Jena (Germany); D. Naidoo, CSIR National Laser Ctr. (South Africa), and Stellenbosch Univ. (South Africa); A. Dudley, CSIR National Laser Ctr. (South Africa); M. Duparre, Friedrich-Schiller-Univ. Jena (Germany)

$8600 \mathrm{OV}$ Modeling of semiconductor saturable absorber mirrors using dynamic mode analysis [8600-33]

C. Pflaum, Univ. Erlangen-Nürnberg (Germany); Z. Rahimi, ASLD GmbH (Germany)

8600 oW Large deformable mirrors for beam control of high brightness lasers [8600-34]

N. Lefaudeux, X. Levecq, Imagine Optic (France); L. Escolano, S. Theis, ISP System (France)

$86000 \mathrm{X} \quad$ Free space propagation without free space [8600-35]

C. Schulze, D. Flamm, M. Duparré, Friedrich-Schiller-Univ. Jena (Germany); A. Forbes, CSIR National Laser Ctr. (South Africa)

8600 OY Selective excitation of higher-order modes in diode-pumped solid-state laser resonators [8600-36]

A. Forbes, S. Ngcobo, CSIR National Laser Ctr. (South Africa) and Univ. of KwaZulu-Natal (South Africa); T. Godin, K. Ait-Ameur, Ecole Nationale Supérieure d'Ingenieurs de Caen et Ctr. de Recherche (France)

BEAM SHAPING AND PHASE DISTORTION I: JOINT SESSION WITH CONFERENCES 8600 AND 8603

$86000 Z$ Brilliant green laser lines for surface processing [8600-37]

M. Ivanenko, W. Grimm, L. Kleinschmidt, A. Krasnaberski, L. Aschke, V. Lissotschenko, LIMO Lissotschenko Mikrooptik GmbH (Germany)

860010 Refractive beam shapers for material processing with high power single mode and multimode lasers [8600-38]

A. Laskin, V. Laskin, AdlOptica Optical Systems GmbH (Germany) 
$860011 \quad$ New monolithic Gaussian-to-Tophat converter with integrated Fourier function and Gaussian-to-Tophat beam splitter [8600-39]

A. Krasnaberski, L. Kleinschmidt, U. Fornahl, M. Ivanenko, LIMO Lissotschenko Mikrooptik GmbH (Germany)

860012 Top hat beam shaping for a high power laser diode bar with a wavelength of $780-1100 \mathrm{~nm}$ [8600-40]

H. Moser, D. Kura, H. Forrer, M. Forrer, FISBA OPTIK AG (Switzerland)

MICRORESONATORS: NOVEL TOPOLOGIES, MATERIALS, AND APPLICATIONS I

860013 Temporal dynamics of Kerr frequency combs in whispering-gallery mode resonators [8600-73]

A. Coillet, I. Balakireva, R. Henriet, L. Larger, Y. Chembo, FEMTO-ST (France)

860014 Coherent perfect absorption in nonlinear optics (Invited Paper) [8600-42]

Y. Zheng, Shanghai Jiao Tong Univ. (China); W. Wan, Shanghai Jiao Tong Univ. (China) and Univ. of Michigan-Shanghai Jiao Tong Univ. Joint Institute (China); X. Chen, Shanghai Jiao Tong Univ. (China)

860015 Fabrication and modelling of truncated oblate and prolate microresonators (Invited Paper) [8600-43]

M. N. Zervas, The Univ. of Southampton (United Kingdom)

860016 Focused ion beam engineered disc resonators [8600-44]

D. C. Aveline, Jet Propulsion Lab. (United States); L. M. Baumgartel, Jet Propulsion Lab. (United States) and Univ. of Southern California (United States); B. Ahn, Univ. of Southern California (United States) and Ajou Univ. (Republic of Korea); G. Lin, N. YU, Jet Propulsion Lab. (United States)

\section{MICRORESONATORS: NOVEL TOPOLOGIES, MATERIALS, AND APPLICATIONS II}

8600 1B Complex polarization states of off-axis uniaxial whispering gallery mode resonators (Invited Paper) [8600-49]

F. Sedlmeir, Friedrich-Alexander Univ. Erlangen-Nurnberg (Germany), and Max Planck Institute for the Science of Light (Germany) and SAOT (Germany); M. Haver, FriedrichAlexander Univ. Erlangen-Nurnberg (Germany); J. U. Fürst, Friedrich-Alexander Univ. Erlangen-Nurnberg (Germany), and Max Planck Institute for the Science of Light (Germany); D. V. Strekalov, Max Planck Institute for the Science of Light (Germany); H. G. L. Schwefel, Friedrich-Alexander Univ. Erlangen-Nurnberg (Germany), and Max Planck Institute for the Science of Light (Germany)

$86001 \mathrm{C}$ Whispering gallery states of neutrons and anti-hydrogen atoms and their applications to fundamental and surface physics (Invited Paper) [8600-24]

V. Nesvizhevsky, Institut Max von Laue-Paul Langevin (France) 
8600 IE On-chip ultrahigh-Q microcavities for highly unidirectional emission (Invited Paper) [8600-52]

X.-F. Jiang, Peking Univ. (China); C.-L. Zou, The Univ. of Science and Technology of China (China); L. Yang, Washington Univ. (United States); Q. Gong, Y.-F. Xiao, Peking Univ. (China)

8600 1G Silicon-based monolithically integrated whispering-gallery mode resonators (Invited Paper) [8600-54] F. Ramiro-Manzano, Univ. degli Studi di Trento (Italy); M. Ghulinyan, Fondazione Bruno Kessler (Italy); N. Prtljaga, Univ. degli Studi di Trento (Italy); G. Pucker, Fondazione Bruno Kessler (Italy); L. Pavesi, Univ. degli Studi di Trento (Italy)

8600 1H Metal-graphene-metal photodetectors (Invited Paper) [8600-55]

T. Mueller, M. Furchi, A. Urich, A. Pospischil, Vienna Univ. of Technology (Austria)

860011 Far-field pattern simulation and measurement for unidirectional-emission circular microlasers (Invited Paper) [8600-56]

Y.-Z. Huang, X.-M. Lv, H. Long, L.-X. Zou, Q.-F. Yao, Y.-D. Yang, X. Jin, M.-Y. Tang, J.-L. Xiao,

Y. Du, The Institute of Semiconductors (China)

\section{MICRORESONATOR SENSORS I}

8600 iN Hybrid organic/inorganic resonators for sensing and telecommunications applications (Invited Paper) [8600-61]

A. M. Armani, N. Deka, A. Harker, A. J. Maker, S. Mehrabani, The Univ. of Southern

California (United States)

\section{MICRORESONATOR SENSORS II}

860010 Whispering gallery mode microresonators: results on aptasensors and on a new sensing approach (Invited Paper) [8600-62]

G. Nunzi Conti, F. Baldini, Istituto di Fisica Applicata Nello Carrara (Italy); S. Berneschi, Istituto di Fisica Applicata Nello Carrara (Italy) and Ctr. Studi e Richerche "Enrico Fermi" (Italy); D. Farnesi, A. Giannetti, S. Soria, C. Trono, Istituto di Fisica Applicata Nello Carrara (Italy); L. Lunelli, L. Pasquardini, C. Pederzolli, Fondazione Bruno Kessler (Italy)

8600 IP Microcavity single virus detection and sizing with molecular sensitivity [8600-63] V. R. Dantham, Polytechnic Institute of New York Univ. (United States); S. Holler, Polytechnic Institute of New York Univ. (United States), and Fordham Univ. (United States); V. Kolchenko, New York City College of Technology (United States); Z. Wan, Hunter College (United States); S. Arnold, Polytechnic Institute of New York Univ. (United States)

$86001 Q \quad$ Flow cytometer system for single-shot biosensing based on whispering gallery modes of fluorescent microspheres [8600-64]

R. Lessard, O. Rousseau-Cyr, M. Charlebois, Univ. Laval (Canada); C. Riviere, O. Mermut, INO (Canada); C. N. Allen, Univ. Laval (Canada) 
8600 IR Beam-coupled microsphere resonators for high-resolution electric field sensing [8600-65] A. R. Ali, T. Ioppolo, M. V. Ötügen, Southern Methodist Univ. (United States)

8600 is Optimization of resonator radial dimensions for quartz enhanced photoacoustic spectroscopy systems [8600-66]

S. L. Firebaugh, U.S. Naval Academy (United States); E. A. Terray, Woods Hole Oceanographic Institution (United States); L. Dong, Shanxi Univ. (China)

MICRORESONATORS: CAVITY QED, OPTOMECHANICS, AND FREQUENCY CONVERSION II

$86001 \mathrm{U}$ Photonic crystal split-beam nanocavities for torsional optomechanics [8600-68] M. Wu, The Univ. of Calgary (Canada) and National Institute for Nanotechnology (Canada); A. C. Hryciw, National Institute of Nanotechnology (Canada); B. Khanaliloo, C. Healey, The Univ. of Calgary (Canada); M. R. Freeman, National Institute for Nanotechnology (Canada), and The Univ. of Alberta (Canada); J. P. Davis, The Univ. of Alberta (Canada); P. E. Barclay, The Univ. of Calgary (Canada), and National Institute for Nanotechnology (Canada)

\section{POSTER SESSION}

860012 Enhancing the radiation efficiency of dye doped microresonators using coupling effects with a suspended core microstructured optical fiber [8600-72]

A. Francois, S. Afshar, K. J. Rowland, M. Henderson, T. M. Monro, The Univ. of Adelaide (Australia)

860020 Microtaper fiber excitation effects in bottle microresonators [8600-74] M. N. Mohd Nasir, M. Ding, G. S. Murugan, M. N. Zervas, The Univ. of Southampton (United Kingdom)

860021 Fabrication and characterization of gain guided, index anti-guided planar waveguide laser resonator [8600-76]

A. Dittli, T.-H. Her, L. Casperson, The Univ. of North Carolina at Charlotte (United States)

860024 Process optimized beam profiles for laser micromachining [8600-79]

C. Bischoff, U. Rädel, U. Umhofer, E. Jäger, TOPAG Lasertechnik GmbH (Germany) 


\title{
Conference Committee
}

\author{
Symposium Chairs
}

Bo Gu, Bos Photonics (United States)

Andreas Tünnermann, Fraunhofer-Institut für Angewandte Optik und Feinmechanik (Germany) and Friedrich-Schiller-Universität Jena (Germany)

Symposium Cochairs

Friedhelm Dorsch, TRUMPF Werkzeugmaschinen GmbH + Co. KG (Germany)

Alberto Piqué, U.S. Naval Research Laboratory (United States)

Program Track Chair

Gregory J. Quarles, Optoelectronics Management Network (United States)

Conference Chairs

Alexis V. Kudryashov, Moscow State Open University (Russian Federation) and Active Optics Night N Ltd. (Russian Federation) Alan H. Paxton, Air Force Research Laboratory (United States)

Vladimir S. Ilchenko, OEwaves, Inc. (United States)

Conference Cochairs

Lutz Aschke, LIMO Lissotschenko Mikrooptik GmbH (Germany)

Kunihiko Washio, Paradigm Laser Research Ltd. (Japan)

Conference Program Committee

Yanne K. Chembo, FEMTO-ST (France)

Jean-Claude M. Diels, The University of New Mexico (United States)

Hans Joachim Eichler, Laser- und Medizin-Technologie GmbH, Berlin

(Germany)

Andrew Forbes, CSIR National Laser Center (South Africa)

Pierre Galarneau, INO (Canada)

Thomas Graf, Universität Stuttgart (Germany)

Tobias J. Kippenberg, Ecole Polytechnique Fédérale de Lausanne (Switzerland)

James R. Leger, University of Minnesota, Twin Cities (United States)

Andrey B. Matsko, OEwaves, Inc. (United States) 
Andrew W. Poon, Hong Kong University of Science and Technology (Hong Kong, China)

Michelle L. Povinelli, The University of Southern California

(United States)

Michael J. Scaggs, Neoteric Concepts, LLC (United States)

Lan Yang, Washington University in St. Lovis (United States)

\section{Session Chairs}

$1 \mathrm{CO}_{2}$ Lasers and Their Beams

Alan H. Paxton, Air Force Research Laboratory (United States)

2 Beam Quality Measurements and Improvement

Alexis V. Kudryashov, Moscow State Open University (Russian

Federation) and Active Optics Night N Ltd. (Russian Federation)

3 Microresonators in Frequency Combs

Vladimir S. Ilchenko, OEwaves, Inc. (United States)

4 Microresonators in Lasers, RF Photonics, THz, and Mid-IR I

Andrey B. Matsko, OEwaves, Inc. (United States)

5 Microresonators in Lasers, RF Photonics, THz, and Mid-IR II

Jean-Claude M. Diels, The University of New Mexico (United States)

6 Microresonators: Cavity QED, Optomechanics, and Frequency

Conversion

Michael J. Scaggs, Haas Laser Technologies, Inc. (United States)

7 Laser Beam Polarization and Laser Resonators

Andrew Forbes, CSIR National Laser Center (South Africa)

8 Laser Beam Formation

James R. Leger, University of Minnesota (United States)

9 Beam Shaping and Phase Distortion I: Joint Session with Conferences 8600 and 8603

Friedhelm Dorsch, TRUMPF Werkzeugmaschinen GmbH + Company KG (Germany)

10 Beam Shaping and Phase Distortion II: Joint Session with Conferences 8600 and 8603

Lutz Aschke, LIMO Lissotschenko Mikrooptik GmbH (Germany)

11 Microresonators: Novel Topologies, Materials, and Applications I

Yanne K. Chembo, FEMTO-ST (France) 
12 Microresonators: Novel Topologies, Materials, and Applications II Michelle L. Povinelli, The University of Southern California (United States)

13 Microresonators in Photonic Lightwave Circuits

Lan Yang, Washington University in St. Louis (United States)

14 Microresonator Sensors I

Vladimir S. Ilchenko, OEwaves, Inc. (United States)

15 Microresonator Sensors II

Andrew W. Poon, Hong Kong University of Science and Technology (Hong Kong, China)

16 Microresonators: Cavity QED, Optomechanics, and Frequency Conversion II

Vladimir S. Ilchenko, OEwaves, Inc. (United States) 
Proc. of SPIE Vol. $8600860001-12$

Downloaded From: https://www.spiedigitallibrary.org/conference-proceedings-of-spie on 26 Apr 2023 Terms of Use: https://www.spiedigitallibrary.org/terms-of-use 